\title{
Modulation of Eicosanoid Metabolism in Endothelial Cells in a Xenograft Model Role of Cyclooxygenase-2
}

\author{
Matilde Bustos, ${ }^{\star}$ Thomas M. Coffman, ${ }^{\ddagger}$ Soheyla Saadi, ${ }^{\star}$ and Jeffrey L. Platt ${ }^{\star \S}$ \\ $*$ Department of Surgery, ${ }^{\ddagger}$ Department of Medicine, and ${ }^{\S}$ Department of Pediatrics and Immunology, Duke University, Durham, \\ North Carolina 27710
}

\begin{abstract}
Lipid inflammatory mediators are thought to play a critical role in the pathogenesis of vascular injury. Among the events which might cause the synthesis of eicosanoids in blood vessels is activation of the complement. To evaluate how complement might influence eicosanoid metabolism, we investigated endothelial cells exposed to xenoreactive antibodies and complement, as might occur in rejecting xenografts where severe vascular injury is a typical feature. While resting porcine aortic endothelial cells released only prostaglandin (PG) $\mathrm{I}_{2}$, endothelial cells stimulated with xenoreactive antibodies and complement released $\mathrm{PGE}_{2}$ and thromboxane $\mathrm{A}_{2}\left(\mathrm{TXA}_{2}\right)$, in addition to increased amounts of $\mathrm{PGI}_{2}$. This alteration in eicosanoid metabolism was associated with induction of cyclooxygenase (Cox)-2 and thromboxane synthase, but not Cox-1. Unlike results seen in other systems, the upregulation of Cox-2 and the subsequent release of eicosanoids by endothelial cells was not directly induced by complement but rather required production of IL$1 \alpha$, which acted on endothelial cells as an autocrine factor. Since eicosanoids have a potent effect on inflammation, vascular tone and platelet aggregation, we postulated that the abnormalities in eicosanoid release induced by xenoreactive antibodies and complement might provide one explanation for the vascular injury, focal ischemia, and thrombosis observed in acute vascular rejection and other vasculitides mediated by complement. (J. Clin. Invest. 1997. 100:1150-1158.) Key words: complement - antibodies • lipid mediators - xenograft $\bullet$ thromboxane synthase
\end{abstract}

\section{Introduction}

Organs transplanted between phylogenetically disparate animals, such as pigs and primates, are subject to rejection that is mediated by the reaction of xenoreactive antibodies and complement of the recipient with the endothelial cells lining the blood vessels of the donor organ $(1,2)$. This reaction leads to functional and morphological changes in endothelium which, over a period of minutes, eventuates in loss of vascular integrity and development of microthrombi, a condition referred to

Address correspondence to Jeffrey L. Platt, M.D., Box 2605, Duke University Medical Center, Durham, NC 27710. Phone: 919-681-3857; FAX: 919-681-7263; E-mail: platt001@mc.duke.edu

Received for publication 5 March 1997 and accepted in revised form 12 June 1997.

J. Clin. Invest.

(C) The American Society for Clinical Investigation, Inc. 0021-9738/97/09/1150/09 \$2.00

Volume 100, Number 5, September 1997, 1150-1158

http://www.jci.org as hyperacute rejection (2-4). If hyperacute rejection is averted, as might be accomplished by depletion of xenoreactive antibodies or inhibition of complement, a condition referred to as acute vascular xenograft rejection often develops over the ensuing days (5). Acute vascular xenograft rejection is characterized by diffuse intravascular coagulation, inflammation, and ischemia. While the pathologic features of acute vascular xenograft reaction are quite dramatic, the pathogenetic events leading to that lesion and the molecular mediators of those events are uncertain.

We have hypothesized that acute vascular xenograft rejection might arise as a consequence of the activation of endothelial cells in the graft, perhaps mediated by the residual xenoreactive antibodies and complement $(5,6)$. According to this concept, endothelial cell activation would be associated with production of procoagulant and proinflammatory molecules that would mediate the histologic changes characteristic of the lesion (7). Consistent with this hypothesis, we have found that formation of the membrane attack complex of complement on endothelial cells induces synthesis of IL- $1 \alpha$ which in turn triggers expression of tissue factor (8) and other procoagulant and proinflammatory molecules. In addition to causing the synthesis of proteins such as tissue factor, complement might contribute to the pathogenesis of vascular injury by triggering synthesis of lipid inflammatory mediators, which could contribute to inflammation and coagulation.

Insult from the membrane attack complex of complement has been shown to stimulate phospholipase $\mathrm{A}_{2}$, the first enzyme in the cascade of eicosanoid synthesis that releases arachidonic acid from membrane fatty acids (9). Once released, arachidonic acid is oxidized to prostaglandin $(P G)^{1} G_{2}$ by Cox or PGH synthase and reduced to $\mathrm{PGH}_{2}$ by the peroxidase activity of the same enzyme. $\mathrm{PGH}_{2}$ is further metabolized through specific enzymatic reactions to form a variety of effector molecules including $\mathrm{PGI}_{2}, \mathrm{PGE}_{2}$, and TXA 2 (10).

Cox has been considered a key rate-limiting enzyme in the synthesis of eicosanoids from arachidonic acid (11). Two isoforms of Cox have been described. Cox-1, is expressed constitutively in most tissues. Cox-2, the other isoform, is not expressed under physiological conditions in most organs, but is induced by cytokines and mitogens during inflammatory processes (12). The regulation of Cox-1 and Cox-2 expression by endothelial cells during immune responses is not well-understood.

Eicosanoid products have potent effects on inflammation, vascular tone, and platelet aggregation. While previous studies have demonstrated important roles for eicosanoids in allograft rejection (13-15), little is known about the characteristics of eicosanoid metabolism in xenografts. Furthermore, the effects

1. Abbreviations used in this paper: Cox, cyclooxygenase; PG, prostaglandin; TXA ${ }_{2}$, thromboxane $\mathrm{A}_{2}$. 
of xenoreactive antibodies and complement on arachidonic acid metabolism by endothelial cells has not been well-characterized.

To test whether the reaction of xenoreactive antibodies and complement with endothelial cells would alter eicosanoid production and induce the expression of Cox, we used a model that recapitulates, in part, the situation that would occur in a xenogeneic organ graft, where porcine aortic endothelial cells serve as a model for a donor organ $(1,16)$. We found that the reaction of xenoreactive antibodies and complement with cultured endothelial cells induces the expression of Cox-2 and thromboxane synthase without affecting expression of Cox-1. However, in contrast to other systems in which activation of complement directly induces eicosanoid synthesis, in endothelial cells, the induction of eicosanoid synthesis by complement is regulated in part by the production of IL- $1 \alpha$, which serves as a molecular intermediate in the induction of Cox- 2 .

\section{Methods}

Materials. Dulbecco's modified Eagle medium (DME), L-glutamine, penicillin, and streptomycin were from Life Technologies (Gaithersburg, MD). FBS was from HyClone Laboratories, Inc. (Logan, UT). An antiserum specific for $\mathrm{TXA}_{2}$ was purchased from Perspective Biosystems (Framington, MA) and antiserum for $\mathrm{PGE}_{2}$ from ICN (Irvine, CA). $\left[{ }^{3} \mathrm{H}\right] \mathrm{TXA}_{2}$ and $\left[{ }^{3} \mathrm{H}\right] \mathrm{PGE}_{2}$ were from Amersham Corp. (Arlington Heights, IL). A competitive antagonist for IL-1 receptors (IL-1 Ra), monoclonal antihuman IL- $1 \alpha$ antibodies, and monoclonal antihuman IL-1 $\beta$ antibodies were from R \& D Systems, Inc. (Minneapolis, MN). Human recombinant IL- $1 \alpha$ was purchased from Genzyme Corp. (Cambridge, MA). Guanidine thiocyanate was from GIBCO BRL (Gaithersburg, MD). [ $\left.\alpha^{32} \mathrm{P}\right] \mathrm{dCTP}$ was from DuPontNew England Nuclear (Boston, MA). Random-priming kits were from Boehringer Mannheim Biochemicals (Indianapolis, IN). Soluble CR1 was a gift of T Cell Sciences, Inc. (Cambridge, MA). A murine Cox- 2 cDNA probe was kindly provided by Dr. Scott Morham (University of North Carolina, Chapel Hill, NC). A murine Cox-1 cDNA probe was purchased from Cayman Chemical Company (Ann Arbor, MI). Rabbit antibodies specific for Cox-1 and Cox-2 and thromboxane-synthase were purchased from Cayman Chemical Company. The Cox-2 inhibitor, S236, was kindly provided by Dr. Karen Seibert (Searle/Monsanto, St. Louis, MO).

Endothelial cell cultures. Porcine aortic endothelial cells were isolated, characterized, and cultured as described previously (8). Endothelial cell monolayers (passages 3-6) were grown to confluence in gelatin-coated $100 \mathrm{~mm}$ Petri dishes, 24-well plates, and chamber slides, and were maintained in DME with $10 \%$ FBS for $72 \mathrm{~h}$ before use.

Stimulation of endothelial cells. Cultured porcine endothelial cells were incubated with diluted human serum as a source of antiendothelial cell antibodies and complement, as previously described $(16,17)$. Except as noted, the human serum was used at concentrations previously shown not to cause endothelial cell death $(16,18)$. Before stimulation of endothelial cells, the culture medium was removed and the cell monolayers were gently washed with prewarmed $\left(37^{\circ} \mathrm{C}\right)$ Hepesbuffered DME. Samples of human serum were separated from blood collected in pyrogen-free containers and allowed to clot at $4^{\circ} \mathrm{C}$. The serum fraction was stored at $-70^{\circ} \mathrm{C}$. Before use of some samples, the serum was heated to $56^{\circ} \mathrm{C}$ for $30 \mathrm{~min}$ to inactivate complement. The titer of antibodies in serum was determined by ELISA as described previously using cultured porcine endothelial cells as targets (18).

Antiporcine endothelial cell antibodies were isolated from human serum by adsorption to cultured endothelial cells followed by thermal extraction, as described previously (17). For some experiments, a human serum that contained very low or undetectable levels of natural antiporcine endothelial cell antibodies was used as a source of complement (19).

For inhibition of Cox-2, a specific inhibitor of the enzyme, S236 (20), was dissolved in DMSO and then was diluted to a final concentration below $1 \%$. Porcine aortic endothelial cells were treated for $1 \mathrm{~h}$ with S236.

Eicosanoid production. After various experimental maneuvers, supernatants from endothelial cells were collected and stored at $-70^{\circ} \mathrm{C}$. The concentrations of $\mathrm{PGI}_{2}$, measured as the stable metabolite 6-keto $\mathrm{PGF}_{1 \alpha}, \mathrm{PGE}_{2}$, and $\mathrm{TXA}_{2}$, measured as the stable metabolite $\mathrm{TXB}_{2}$, were determined by radioimmunoassay. Experimental samples (measured in duplicate) and standards (measured in triplicate) were incubated with a mixture consisting of a specific antiserum and a known amount of ${ }^{3} \mathrm{H}$ standard overnight at $4^{\circ} \mathrm{C}$. After incubation, free eicosanoids were adsorbed with dextran-coated charcoal. The concentration of eicosanoids was determined using a standard curve in which the log of the concentration was plotted against the log of $\mathrm{B} / \mathrm{B}_{0}$. Experiments were performed using two different endothelial cell lines. The cell densities were similar for all the experiments.

RNA isolation and Northern analysis. After stimulation with $10 \%$ human or control buffer, confluent porcine aortic endothelial cells were washed once in warm Hepes buffer and then total cellular RNA was isolated by direct lysis of cells using $4 \mathrm{M}$ guanidinium isothiocyanate followed by phenol/chloroform extraction and isopropanol precipitation according to Chomczynski and Sacchi (21). For Northern blot analysis, total RNA (10 $\mu \mathrm{g}$ per lane) was denatured in deionized

A

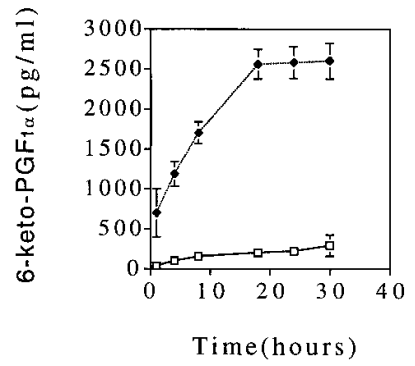

B

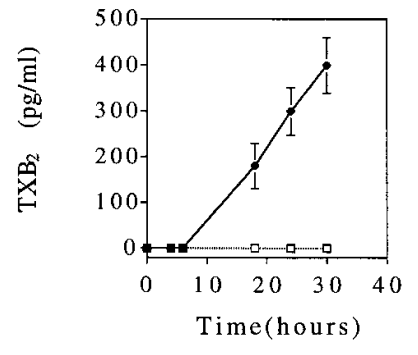

C

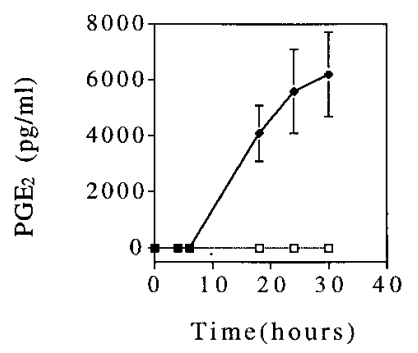

Figure 1. Eicosanoid release from porcine aortic endothelial cells after stimulation by antiendothelial cell antibodies and complement. Confluent monolayers of porcine endothelial cells were treated with $10 \%$ human serum containing xenoreactive natural ment $(\diamond)$. Media were collected at various times and eicosanoids in the media were measured by RIA. Medium lacking serum was used as a control ( $\square)$. Each point represents the mean \pm SEM for three experiments. $(A) \mathrm{PGI}_{2}$ measured as the stable metabolite 6-ketoPGF $_{1 \alpha}$. (B) TXA 2 measured as the stable metabolite $\mathrm{TXB}_{2} .(C)$ $\mathrm{PGE}_{2}$. antibodies and comple- 


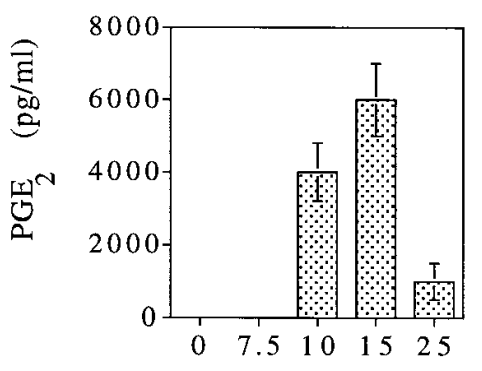

$\mathrm{Ab}+\mathrm{C}(\%$ human serum)
Figure 2. Release of $\mathrm{PGE}_{2}$ from porcine aortic endothelial cells stimulated by varying amounts of xenoreactive natural antibodies and complement. Monolayers of porcine aortic endothelial cells were incubated for $10 \mathrm{~h}$ with various concentrations of human serum as a source of xenoreactive natural antibodies and complement $(A b+C)$. $\mathrm{PGE}_{2}$ released into the medium was measured by RIA. Synthesis of $\mathrm{PGE}_{2}$ was maximum at serum concentration of $15 \%$. A serum concentration of $25 \%$ caused lysis of some endothelial cells with consequent decrease of prostaglandin release. The mean \pm SEM is shown.

formamide and formaldehyde in a Mops buffer and size fractionated on $1 \%$ agarose gels. RNA was transferred to nylon membranes and cross-linked by UV irradiation. Nylon membranes were prehybridized in Quick-Hyb solution for $30 \mathrm{~min}$ and then hybridized for $2 \mathrm{~h}$ with an appropriate cDNA probe which had been $\left[\alpha^{32} \mathrm{P}\right]$ labeled by random priming. To control for variability in the quantity of RNA loaded, membranes were later probed with $\beta$-actin. Autoradiography was performed using Kodak XAR film (Eastman Kodak Co., Rochester, NY). Films were scanned and analyzed using a scanner (model 9600; Relisys, Milpitas, CA) and software (Image 1.43; National Institutes of Health Shareware, Bethesda, MD).

Detection of Cox and thromboxane synthase by immunofluorescence. Expression of Cox-1, Cox-2, and thromboxane synthase proteins was analyzed by immunofluorescence using porcine endothelial cells grown in chamber slides (Lab-Tek, Naperville, IL). Endothelial cell monolayers were washed gently with prewarmed $\left(37^{\circ} \mathrm{C}\right)$ Hepesbuffered DME and fixed with acetone/methanol (1:1, vol/vol). The endothelial cells were then incubated with rabbit antibodies specific for human Cox-1, Cox-2, or thromboxane-synthase for $30 \mathrm{~min}$ at room temperature. The cultured cells were then washed, and fluorescein isothiocyanate-labeled goat anti-rabbit IgG added and incubated for $30 \mathrm{~min}$ at room temperature. The cells were then washed again and mounted in Vectashield. The intensity and localization of immunofluorescence was then assessed using a Nikon fluorescence microscope.

Statistical analysis. All values were expressed as mean \pm SEM. For statistical analysis, we used the unpaired Student's $t$ test for two-group comparisons. Differences were considered significant at $P<0.05$.

\section{Results}

Production of eicosanoids by porcine aortic endothelial cells. Quiescent cells produced small amounts of $\mathrm{PGI}_{2}$, but did not release detectable amounts of $\mathrm{PGE}_{2}$ or TXA 2 (Fig. 1). The effects of xenoreactive antibodies and complement on production of eicosanoids by porcine endothelial cells were tested by treating the endothelial cells with human serum. After incubation for $8 \mathrm{~h}$ in diluted human serum at concentration known to stimulate endothelial cells but not to cause cytolysis (18), cultured endothelial cells released $\mathrm{TXB}_{2}, \mathrm{PGE}_{2}$, and increased amounts of 6-keto- $\mathrm{PGF}_{1 \alpha}$ into the medium (Fig. 1). The release of these eicosanoids increased with time and remained elevated above baseline for up to $24 \mathrm{~h}$. Increased production of 6-keto- $\mathrm{PGF}_{1 \alpha}$ by endothelial cells was observed as soon as $1 \mathrm{~h}$ after exposure to human serum and remained elevated for up to $24 \mathrm{~h}$. Since endothelial cells do not store eicosanoids, the release of 6 -keto- $\mathrm{PGF}_{1 \alpha}, \mathrm{TXB}_{2}$, and $\mathrm{PGE}_{2}$ suggests that de novo synthesis had occurred. In repeated experiments, the level of prostaglandin synthesis varied directly with the concentration of human serum used, maximum production being observed at $15 \%$ serum, as shown in Fig. 2. A decrease in eicosanoid synthesis at concentrations of human serum above $15 \%$ probably reflects lysis of the treated cells which was observed visually.

Induction of mRNA for Cox isoforms by antibodies and complement. To determine whether the stimulation of eicosanoid synthesis by xenoreactive antibodies plus complement might reflect altered expression of cyclooxygenase isoenzymes, porcine endothelial cells were exposed to human serum as described above and the expression of Cox-1 and Cox-2 mRNA was assayed by Northern blotting. As expected, quiescent endothelial cells had a low level of Cox-1

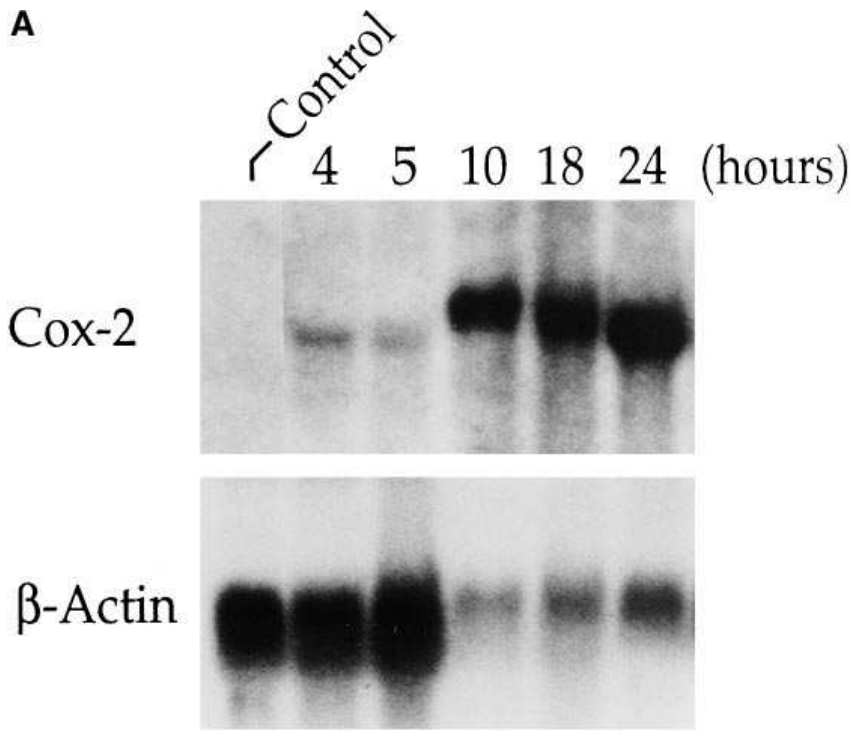

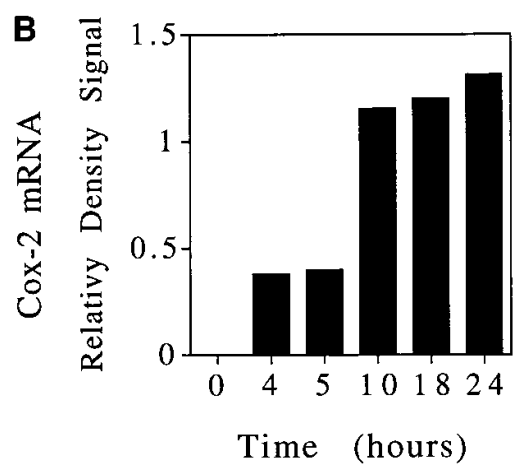
ex- $/ \beta$-actin mRN. Results demonstrate that activation

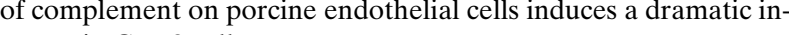
crease in Cox- 2 cells. 

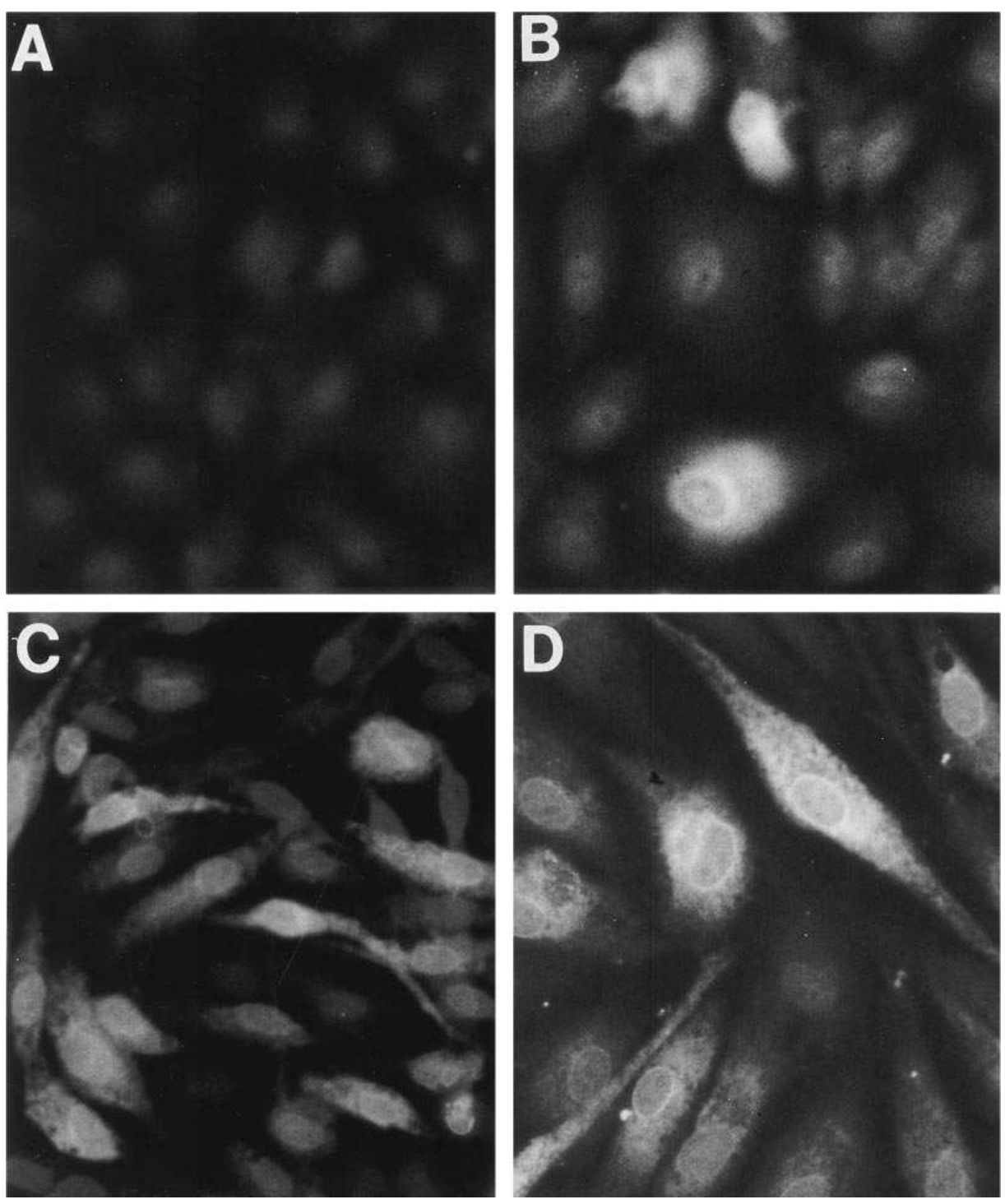

Figure 4. Immunofluorescence localization of Cox-2 in resting endothelial cells and endothelial cells stimulated by xenoreactive antibodies and complement. Binding of anti-Cox-2 antibodies to porcine endothelial cells was investigated by indirect immunofluorescence $(A)$ Resting endothelial cells. Cox-2 was not detectable. (B) Endothelial cells incubated with xenoreactive antibodies and complement for $6 \mathrm{~h}$. Cox-2 is detected close to the nucleus $(\times 400)$. (C) Endothelial cells stimulated with xenoreactive antibodies plus complement for $14 \mathrm{~h}$. The level of Cox-2 protein was increased as is the number of positive endothelial cells $(\times 200)$. $(D)$ Endothelial cells stimulated with xenoreactive antibodies plus complement for $24 \mathrm{~h}$. Cox- 2 protein remained positive and is located in the cytoplasm $(\times 400)$.
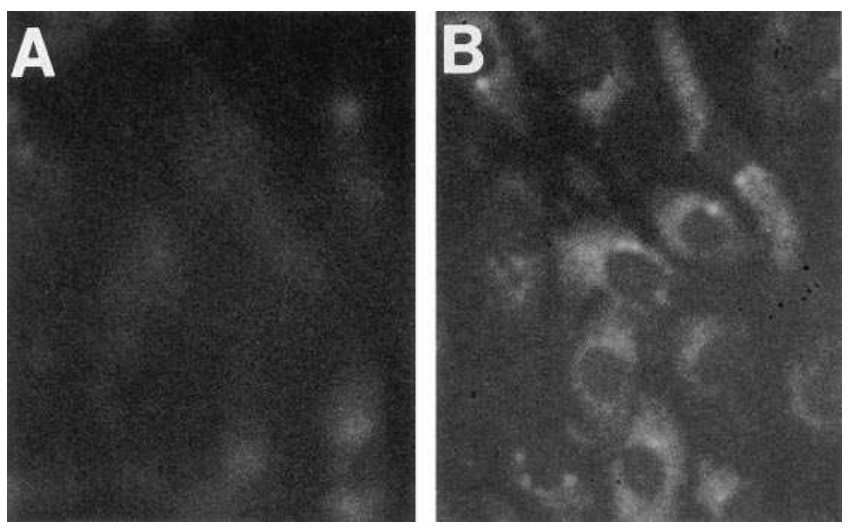

Figure 5. Immunofluorescence staining for thromboxane synthase in resting endothelial cells and endothelial cells stimulated with xenoreactive antibodies and complement. $(A)$ Resting endothelial cells. Thromboxane synthase was not detectable. $(B)$ Endothelial cells stimulated with xenoreactive antibodies for $10 \mathrm{~h}$. Thromboxane synthase was detectable in the cytoplasm after $10 \mathrm{~h}$ of incubation $(\times 400)$.
mRNA (data not shown) and no detectable Cox-2 mRNA. After the stimulation of endothelial cells with xenoreactive antibodies and complement, expression of Cox-2 mRNA was detected at $4 \mathrm{~h}$ and the level of expression increased with time (Fig. 3).

Localization of Cox-2, Cox-1, and thromboxane synthase proteins in endothelial cells. Expression of Cox-1, Cox-2, and thromboxane synthase were analyzed by immunofluorescence microscopy. Quiescent porcine endothelial cells expressed Cox-1 but neither Cox-2 nor thromboxane synthase. Expression of Cox-1 was not altered after stimulation of the cells by xenoreactive antibodies and complement. After $6 \mathrm{~h}$ of stimulation, Cox-2 protein was detected in a perinuclear location (Fig. $4 \mathrm{~B}$ ). The expression of thromboxane synthase was detected at $10 \mathrm{~h}$ as a weak cytoplasmic fluorescence (Fig. 5). After longer durations of incubation with human serum, the number of positive cells and intensity of Cox-2 fluorescence increased and a more cytoplasmic localization was seen (Fig. $4 \mathrm{D}$ ), while the expression and localization of thromboxane synthase did not increase further. 
A

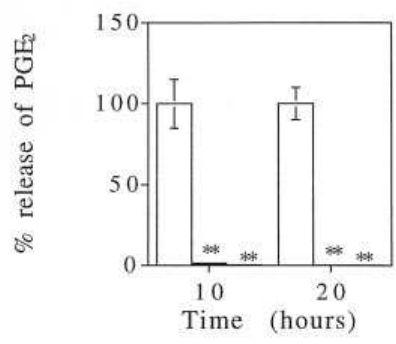

B

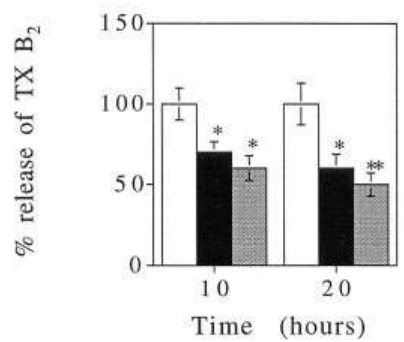

C

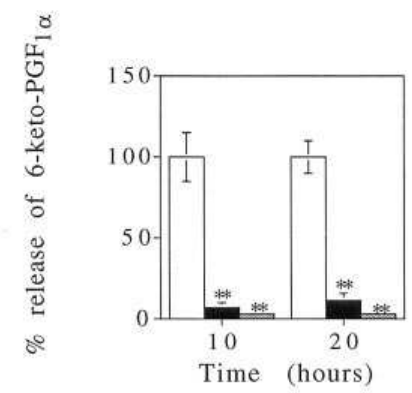

Figure 6. Effect of S236, a specific inhibitor for Cox-2, on synthesis of $\mathrm{PGE}_{2}, \mathrm{TXA}_{2}$, and $\mathrm{PGI}_{2}$ by endothelial cells stimulated with xenoreactive antibodies plus complement. Cells were incubated with medium containing $10 \mu \mathrm{M}$ or $100 \mu \mathrm{M}$ of S236 for $1 \mathrm{~h}$ and then with medium containing xenoreactive antibodies and complement for either 10 or $20 \mathrm{~h}$. (A) $\mathrm{PGE}_{2}$. The release of $\mathrm{PGE}_{2}$ was completely abrogated. $(B)$ $\mathrm{TXA}_{2}$. The levels of $\mathrm{TXA}_{2}$, measured as the stable metabolite $\mathrm{TXB}_{2}$, were reduced by $50 \%$. (C) $\mathrm{PGI}_{2}$. Production of $\mathrm{PGI}_{2}$, measured as the stable metabolite 6-keto$\mathrm{PGF}_{1 \alpha}$, was nearly undetectable. Open bar, $\mathrm{Ab}+\mathrm{C}$; solid bar, $\mathrm{AB}+\mathrm{C}+10 \mu \mathrm{M}$ S236; shaded bar, $\mathrm{Ab}+\mathrm{C}+$ $100 \mu \mathrm{M}$ S236. $*(P<$ $0.05), * *(P<0.025)$ (unpaired Student's $t$ test).

Inhibition of Cox-2 reduces eicosanoid production in endothelial cells. The finding that the action of xenoreactive antibodies and complement on endothelial cells increased the expression of Cox-2 without modification of Cox- 1 and increased the release of eicosanoids raised the question whether Cox-2 alone is responsible for the altered synthesis in this system. To address that question, porcine aortic endothelial cells were incubated with a specific inhibitor of Cox-2, S236, for $1 \mathrm{~h}$ and then stimulated with xenoreactive antibodies and complement. The amount of eicosanoid production was analyzed by radioimmunoassay as described above and expressed as percentage of inhibition of the total production. As Fig. 6 shows, inhibition of Cox-2 completely prevented production of $\mathrm{PGE}_{2}$ and $\mathrm{PGI}_{2}$ as measured by 6 -keto- $\mathrm{PGF}_{1 \alpha}$, and inhibited the production of $\mathrm{TXA}_{2}$, as measured by $\mathrm{TXB}_{2}$, by $50 \%$. The amount of $\mathrm{PGI}_{2}$ as measured by 6-keto- $\mathrm{PGF}_{1 \alpha}$ released in the presence of S236 was comparable to basal levels of production, presumably reflecting activity of Cox-1 and suggesting that S236 was not a general inhibitor of prostaglandin synthesis.

Role of complement in the expression of Cox and production of eicosanoids. Four lines of evidence suggested that the production of eicosanoids by endothelial cells exposed to human serum reflected activation of complement brought about by the binding of complement-fixing xenoreactive antibodies in human serum. First, Cox-2 mRNA expression on endothelial cells was not induced by treating endothelial cells with hu-

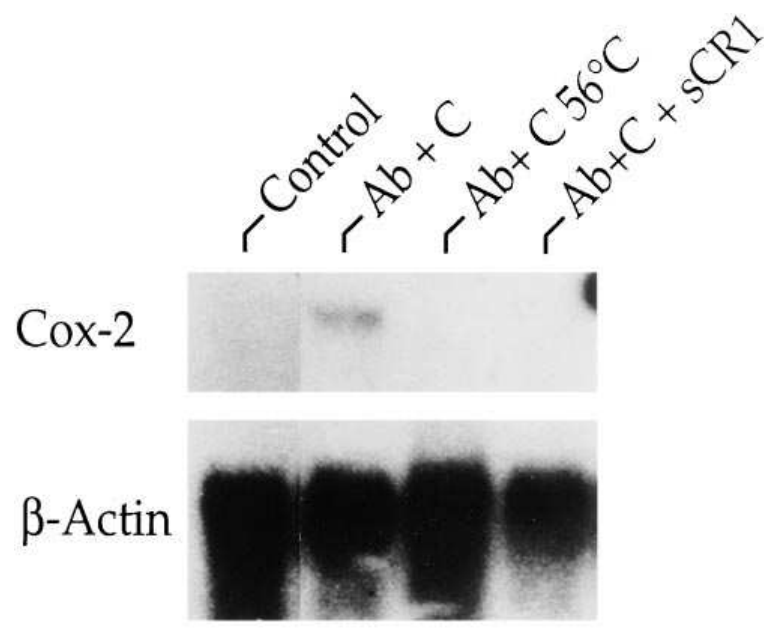

Time (hours): $5 \mathrm{~h}$

Figure 7. Role of complement in the expression of Cox-2 mRNA. The role of complement in the induction of Cox-2 mRNA was investigated by Northern blotting of mRNA from cultured endothelial cells exposed to various stimuli. Porcine aortic endothelial cells were stimulated with human serum as a source of xenoreactive antibodies and complement $(A b+C)$; human serum heated to $56^{\circ} \mathrm{C}$ for $30 \mathrm{~min}$ to inactivate complement $\left(A b+C 56^{\circ} \mathrm{C}\right)$ and human serum with sCR1 $(6 \mu \mathrm{g} / \mathrm{ml})$, which inhibits $\mathrm{C} 3$ convertase $(A b+C+s C R 1)$. After $5 \mathrm{~h}$, mRNA was analyzed in Northern blot hybridized with Cox-2 cDNA. Expression of Cox-2 was observed only after incubation with xenoreactive antibodies and complement. The inhibition of complement completely abolished the expression of Cox-2.

man serum in which complement activation was inhibited by heating or by adding sCR1, which inhibits C3 convertase, for $5 \mathrm{~h}$, a time when primary induction of complement induced genes is observed (8) (Fig. 7). Second, endothelial cells treated with human serum lacking xenoreactive antibodies but having intact complement, failed to exhibit Cox-2 mRNA expression (Fig. 8). Third, Cox-2 protein and thromboxane synthase were not detected by immunofluorescence after stimulation with xenoreactive antibodies alone. Fourth, endothelial cells treated with human serum in which complement was inactivated by heating or adding sCR1, released $\mathrm{PGE}_{2}$ and $\mathrm{TXA}_{2}$ in only very small amounts (Fig. 9). Finally, endothelial cells treated with human serum containing very low levels of xenoreactive natural antibodies induced the production of $\mathrm{PGE}_{2}$ and $\mathrm{TXA}_{2}$ in small amounts, comparable to those induced by serum containing sCR1 or heat-inactivated serum (not shown).

Taken together these results suggest that the synthesis of eicosanoids in this system depends on activation of complement, which in turn depends on binding of complement-fixing antibodies. However, these results do not exclude the possibility that other components of serum contribute to the stimulation of endothelial cells.

Role of IL-1 in the production of eicosanoids and expression of Cox. Recently, we observed that the activation of human complement on porcine endothelial cells stimulates synthesis of tissue factor, but that tissue factor synthesis is not a direct response to complement; rather, its synthesis in this system is governed by the synthesis of IL-1 $\alpha$ (8). We asked, therefore, whether IL-1 might also serve as an intermediary in the production of eicosanoids as induced by antiendothelial cell anti- 

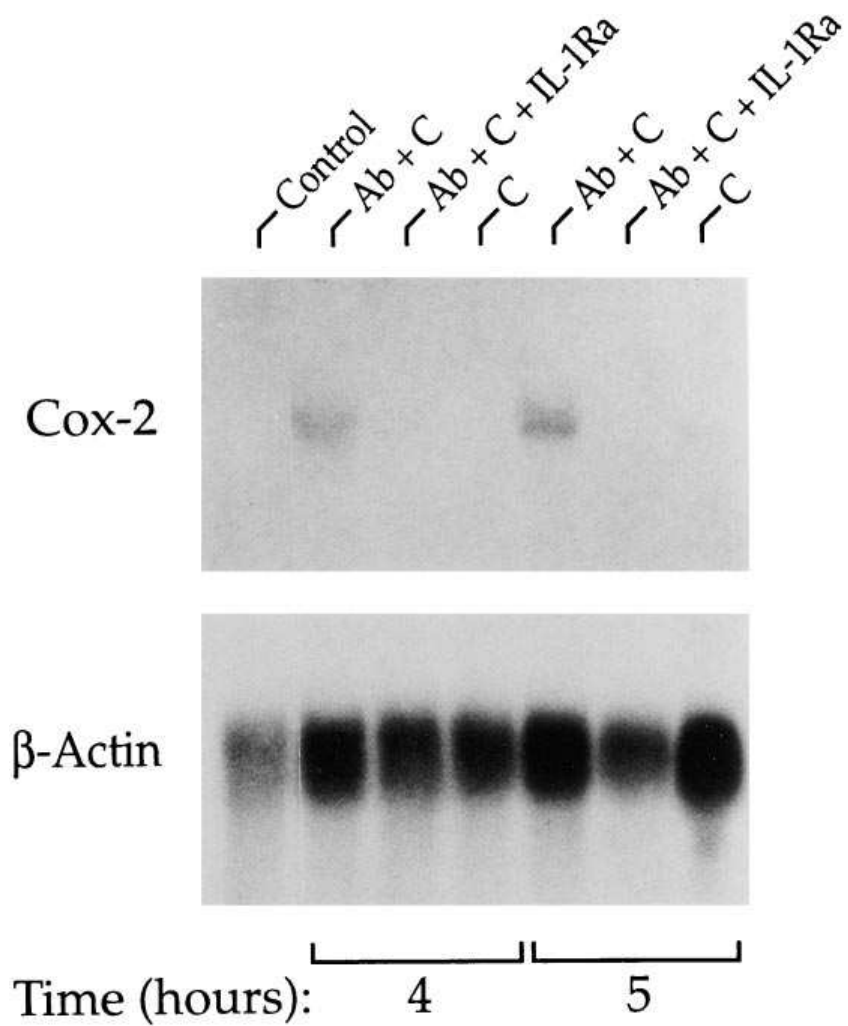

Figure 8. Role of complement and IL- $1 \alpha$ in expression of Cox-2 mRNA in endothelial cells after stimulation with human serum. Confluent monolayers of porcine aortic endothelial cells were incubated with $10 \%$ human serum as a source of xenoreactive antibodies and complement $(A b+C)$, human serum plus $50 \mathrm{ng} / \mathrm{ml}$ of IL-1 receptor antagonist $(A b+C+I L-1 R a)$ or an human serum lacking antiendothelial cell antibodies $(C)$. After 4 or $5 \mathrm{~h}$ of incubation, total mRNA was isolated and probed for Cox-2. Endothelial cells incubated with human serum containing $\mathrm{Ab}+\mathrm{C}$ expressed $\mathrm{Cox}-2$. However, human serum containing IL-1 Ra or with human serum lacking xenoreactive antibodies but containing complement did not express Cox- 2 mRNA.

bodies and complement or whether activation of complement induces eicosanoid synthesis directly as it does in other systems. To address this question, IL-1 receptor antagonist was added to human serum which, in turn, was incubated with endothelial cells and eicosanoid production was measured as described above. As Fig. 10 shows, the addition of IL-1 receptor antagonist to the human serum prevented the release of $\mathrm{PGE}_{2}$ and $\mathrm{TXA}_{2}$ from endothelial cells stimulated with that serum. This result suggested that production and release of IL-1 was a necessary step in the production of eicosanoids by endothelial cells in response to complement. Consistent with this concept, treatment of endothelial cells with human serum containing IL-1 receptor antagonist prevented the expression Cox-2 mRNA (Fig. 8). Whether IL- $1 \alpha$ or IL-1 $\beta$ was responsible for the increase of Cox-2 in this system was then investigated in studies using blocking anti-IL-1 $\alpha$ antibodies or blocking antiIL-1 $\beta$ antibodies. As Fig. 11 shows, the addition of blocking anti-IL-1 $\alpha$ antibodies to a stimulating serum significantly inhibited the production of Cox-2 mRNA, while the addition of human IL-1 $\beta$ antibodies to the stimulating serum had no ap-

A

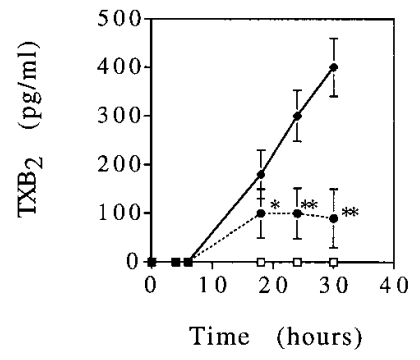

B

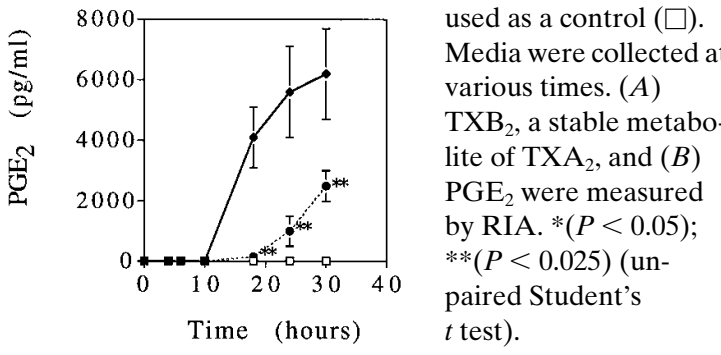

preciable effect. Consistent with this result, porcine endothelial cells stimulated with human serum expressed IL-1 $\alpha$ mRNA (Fig. $12 A$ ) but not IL-1 $\beta$ mRNA (not shown) and treatment of endothelial cells with IL-1 $\alpha$ induced expression of Cox-2 mRNA (Fig. 12 B). Taken together, these results sug-

A

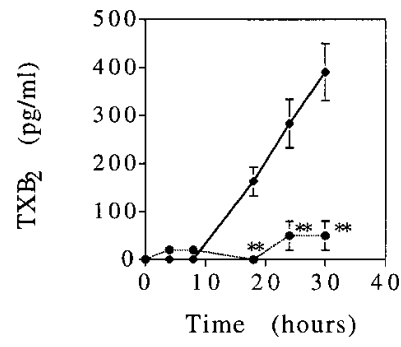

B

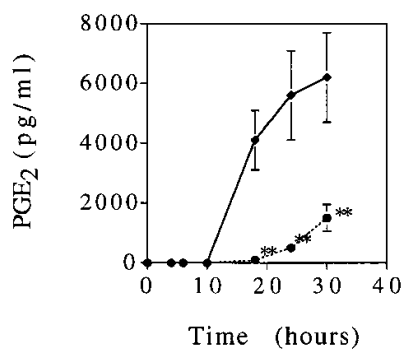

Figure 10. Role of IL-1 in the release of $\mathrm{TXA}_{2}$ and $\mathrm{PGE}_{2}$ by endothelial cells stimulated with xenoreactive antibodies and complement. Confluent monolayers of porcine aortic endothelial cells were incubated with $10 \%$ human serum as a source of xenoreactive antibodies and complement $(\diamond)$ or with human serum containing $50 \mathrm{ng} / \mathrm{ml}$ of IL-1 receptor antagonist (•). Eicosanoids released from endothelial cells were measured by RIA. $(A)$ TXA $_{2}$, measured as the stable metabolite $\mathrm{TXB}_{2}$ and (B) PGE 2 . IL-1 receptor antagonist inhibited production of $\mathrm{TXA}_{2}$ and $\mathrm{PGE}_{2}$ significantly suggesting that expression of IL-1 is an essential step in complement mediated synthesis of eicosanoids. $* *(P<0.025)$ (unpaired Student's $t$ test). 
gest that IL-1 $\alpha$ serves as an autocrine factor inducing the synthesis of eicosanoids by increasing expression of Cox- 2 .

\section{Discussion}

Owing to its location at the interface between the blood and tissues, vascular endothelium is ideally situated to control tissue responses in immunity. The interactions between blood and endothelium are capable of modulating the function of leukocytes, platelets, and smooth muscle cells (22). Among the most potent products of endothelial cells, which might regulate the function of neighboring cells, are eicosanoids. Eicosanoids control the state of activation of leukocytes and platelets, the contractile properties of vascular smooth muscle, and the coagulant posture of the blood vessel wall (23). We studied porcine aortic endothelial cells stimulated with antiendothelial cell antibodies and complement as a model to evaluate the potential contribution of eicosanoids to the reactions which might take place in a xenogeneic organ graft undergoing acute vascular xenograft rejection. This type of rejection occurs within days after transplantation and is characterized by diffuse intravascular coagulation and rapid influx of neutrophils and macrophages (5), making acute xenograft rejection an extreme model for analysis of the potential role of eicosanoid metabolism in the pathogenesis of disease. Our studies revealed that endothelial cells stimulated with antiendothelial cell antibodies and complement did indeed produce increased amounts of prostaglandins and thromboxane through the induction of Cox-2. However, in contrast to the effects in other systems (24), complement did not induce eicosanoid production directly; rather, complement induced the synthesis and secretion of IL- $1 \alpha$, which acted on endothelial cells as an autocrine factor inducing the change in eicosanoid metabolism that ensue.

Although endothelial cells are generally considered an important source of $\mathrm{PGI}_{2}$ (10), the capacity of endothelium to elaborate other eicosanoids, such as $\mathrm{PGE}_{2}$ and $\mathrm{TXA}_{2}$, in the course of the inflammation and immune responses has not been well-documented. Our data support previous studies that suggest that upregulation of Cox-2 in inflammatory states allows the cell to modify its capacity to generate eicosanoids. In

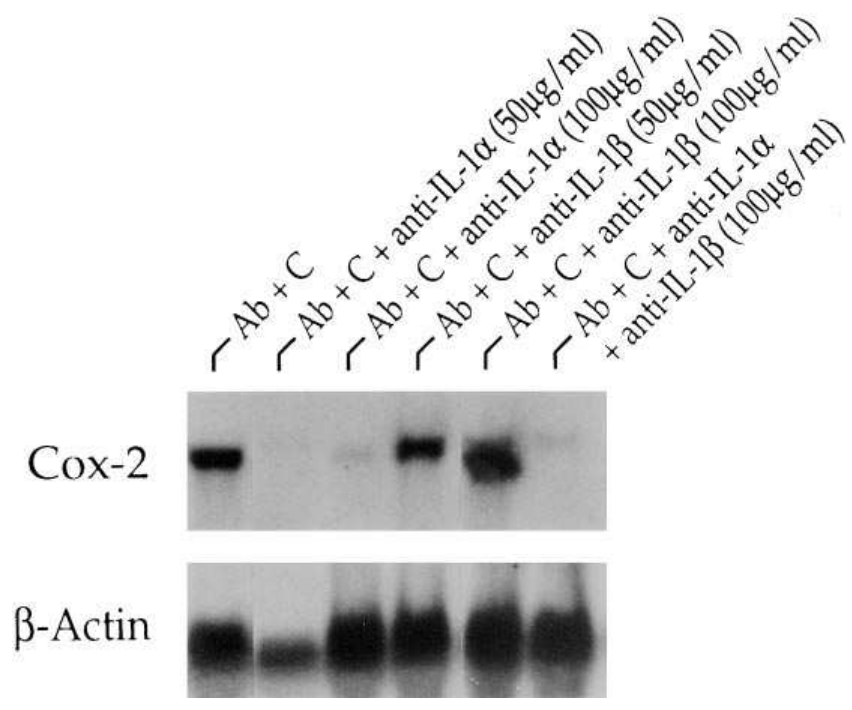

Figure 11. Role of IL- $1 \alpha$ versus IL-1 $\beta$ in the expression of Cox-2 mRNA in endothelial cells stimulated with complement. Confluent monolayers of porcine aortic endothelial cells were incubated with xenoreactive antibodies and complement $(A b+C)$, xenoreactive antibodies and complement plus anti-IL- $1 \alpha$ antibodies $(A b+C+$ anti-IL-1 $\alpha$ ); xenoreactive antibodies and complement plus antiIL-1 $\beta$ antibodies $(A b+C+$ anti-IL-1 $\beta)$ or xenoreactive antibodies and complement plus anti-IL-1 $\alpha$ antibodies and anti-IL-1 $\beta$ antibodies $(A b+C+$ anti-IL-1 $\alpha+$ anti-IL-1 $\beta)$ for $5 \mathrm{~h}$. Cox- 2 mRNA expression was analyzed by Northern blot.

other studies in endothelial cells, Cox-2 expression has been associated with enhanced cellular capacity to generate $\mathrm{PGI}_{2}$, but a role in modulating synthesis of $\mathrm{TXA}_{2}$ and $\mathrm{PGE}_{2}$ has not been established. Ramadan et al. (25) have shown previously that endothelial cells are capable of synthesizing thromboxane under certain circumstances and Carreras and Maclouf have suggested that antibody binding may alter the balance between endothelial production of $\mathrm{PGI}_{2}$ and $\mathrm{TXA}_{2}$ (26). Karin et al. (27) showed recently that production of thromboxane by human umbilical vein endothelial cells was associated with induction of Cox-2. However, in these previous studies, the
A
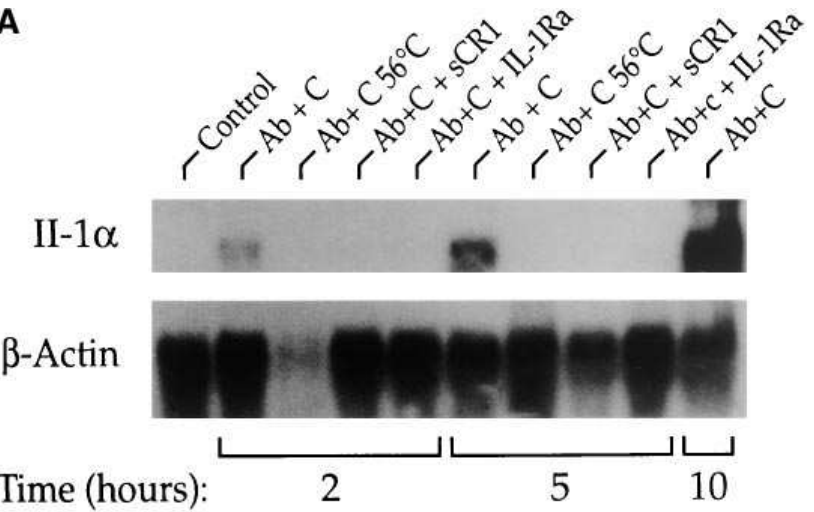

B

\section{Cox-2}

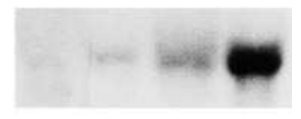

$\beta$-Actin

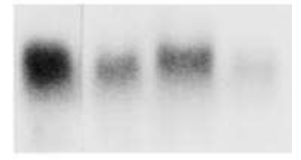

Time (hours)
Figure 12. Role of xenoreactive antibodies plus complement in the expression of IL-1 and Cox-2 in endothelial cells. (A) Induction of IL- $1 \alpha$ by xenoreactive antibodies and complement. Porcine endothelial cells were treated with $10 \%$ human serum containing xenoreactive antibodies plus complement $(A b+C)$, heat inactivated human serum $(A b+C$ $56^{\circ} \mathrm{C}$ ) or human serum plus sCR1 $(A b+C+s C R 1)$. After 2,5 , and $10 \mathrm{~h}$, mRNA was extracted and hybridized with a

porcine IL- $\alpha$ cDNA probe. IL-1 $\alpha$ appears after $2 \mathrm{~h}$ of incubation, increasing at 5 and $10 \mathrm{~h}$. (B) Induction of Cox- $2 \mathrm{mRNA}$ by IL-1 $\alpha$. The ability of IL- $1 \alpha$ to induce Cox- 2 mRNA in porcine endothelial cells was tested directly by exposing cultured cells to $800 \mathrm{U} / \mathrm{ml}$ of human recombinant IL- $1 \alpha$ for varying periods of time and then testing for Cox- 2 mRNA by Northern blot as described above. A progressive increase in Cox- 2 mRNA is observed. 
mechanisms by which these alterations occurred and the casual role of Cox-2 in this process was not explored.

Here, we show that complement activation on endothelial cells markedly alters the metabolism of cyclooxygenase products. This alteration in eicosanoid metabolism is observed within $1 \mathrm{~h}$, where endothelial cells began to produce large amounts of the prostacyclin metabolite 6-keto-PGF1 $\alpha$, but very little of $\mathrm{PGE}_{2}$ and $\mathrm{TXA}_{2}$. This early response probably reflects activation of phospholipases releasing arachidonic acid that is metabolized to $\mathrm{PGI}_{2}$, the major metabolite produced by normal endothelial cells (10). However, over a period of 8-10 h endothelial cells begin to synthesize large amounts of $\mathrm{TXA}_{2}$ and $\mathrm{PGE}_{2}$. This later change is associated with enhanced expression of Cox-2. This enhancement of Cox-2 expression plays a key role in stimulating $\mathrm{PGE}_{2}$ production since $\mathrm{PGE}_{2}$ production is almost completely abrogated by the specific Cox-2 inhibitor. In contrast, the Cox-2 inhibitor caused only a partial reduction in $\mathrm{TXA}_{2}$ synthesis, suggesting that the regulation of thromboxane synthesis in endothelial cells is more complex than $\mathrm{PGE}_{2}$ and may be linked, in part, to Cox-1.

The proinflammatory molecule IL-1 is known to be an important molecule regulator of eicosanoid metabolism. For example, IL- $1 \alpha$ and IL- $1 \beta$ increase the endogenous release of arachidonic acid and stimulate the synthesis of eicosanoids in response to arachidonic acid (28). IL-1 stimulates the expression of mRNA of Cox-2, secretory PLA 2 (29-31), and cytosolic $\mathrm{PLA}_{2}$ (32). The finding that complement induces IL-1 $\alpha$, which in turn induces Cox-2 and thromboxane synthase is, however, a novel regulatory mechanism, which may place eicosanoid metabolism, causing a profound alteration in both the level and profile of eicosanoid synthesis. We speculate that the ability of IL- $1 \alpha$ to act as an autocrine factor may also depend on blood flow in the region of the affected endothelium. Thus, at sites of ischemia or where blood flow is slow, IL-1 $\alpha$ produced in response to complement can change eicosanoid metabolism, while under conditions of physiologic blood flow the IL- $1 \alpha$ might be carried away. This concept suggests that regional blood flow could have a profound impact on the manifestations of reperfusion injury and humoral responses.

The observation that Cox- 2 in endothelial cells was located at different sites in endothelial cells at various times relative to antibody and complement exposure, raises a question about whether the location of Cox-2 could influence localized production of eicosanoids. For example, the expression of Cox-2 in the vicinity of the nucleus shortly after stimulation of endothelial cells might promote the actions of eicosanoids on the nucleus. Consistent with this idea, recent studies have shown that a prostaglandin $\mathrm{J}_{2}$ derivative acts through a nuclear receptor, the transcription factor PPAR- $\gamma$, without using the usual second messenger pathways and plays an important role in cell cycle arrest and apoptosis (33). The cytoplasmic distribution of Cox-2 at later times may lead to synthesis of eicosanoids that are exported from the cell. Our findings are the first to describe these dynamic patterns of intracellular localization for Cox-2 in endothelial cells.

If eicosanoid metabolism is important in the pathogenesis of vascular rejection, as some would suggest (15), then the events that figure into the changes in cyclooxygenase levels are probably of critical pathogenetic importance. For many years, complement activation has been implicated de novo synthesis of lipid mediators. Our findings now suggest that this relationship is more complex than previously supposed and that the physiology of blood flow may impact at a molecular level in this process.

\section{Acknowledgments}

We thank Dr. Scott Morham for providing Cox-2 cDNA, Dr. Karen Seibert for the Cox-2 inhibitor and S236, and Patrick Flannery for technical assistance.

This work was supported by National Institutes of Health grants HL50985, HL46810, HL52297, and DK38108. M. Bustos was supported by Ministerio de Educacion y Ciencia (Spain).

\section{References}

1. Platt, J.L., G.M. Vercellotti, A.P. Dalmasso, A.J. Matas, R.M. Bolman, J.S. Najarian, and F.H. Bach. 1990. Transplantation of discordant xenografts: a review of progress. Immunol. Today. 11:450-456.

2. Parker, W., S. Saadi, S.S. Lin, Z.E. Holzknecht, M. Bustos, and J.L. Platt. 1996. Transplantation of discordant xenografts: a challenge revisited. Immunol. Today. 17:373-378.

3. Leung, D.Y., J.L. Moake, P.L. Havens, M. Kim, and J.S. Pober. 1988 Lytic anti-endothelial cell antibodies in haemolytic-uraemic syndrome. Lancet. 2:183-186.

4. Lawson, J.H., and J.L. Platt. 1996. Molecular barriers to xenotransplantation. Transplantation (Baltimore). 62:303-310.

5. Leventhal, J.R., A.J. Matas, L.H. Sun, S. Reif, R.M. Bolman III, A.P. Dalmasso, and J.L. Platt. 1993. The immunopathology of cardiac xenograft rejection in the guinea pig to rat model. Transplantation (Baltimore). 56:1-8.

6. Platt, J.L. 1994. A perspective on xenograft rejection and accommodation. Immunol. Rev. 141:127-149.

7. Saadi, S., N.S. Ihrcke, and J.L. Platt. 1996. Pathophysiology of xenograft rejection. In Principles of Immunomodulatory Drug Development in Transplantation and Autoimmunity. R. Lieberman and R. Morris, editors. Raven Press, Ltd., New York. 31-45.

8. Saadi, S., R.A. Holzkhecht, C.P. Patte, D.M. Stern, and J.L. Platt. 1995. Complement-mediated regulation of tissue factor activity in endothelium. $J$. Exp. Med. 182:1807-1814.

9. Imagawa, D.K., N.E. Osifchin, L.E. Ramm, P.G. Koga, C.H. Hammer, H.S. Shin, and M.M. Mayer. 1986. Release of arachidonic acid and formation of oxygenated derivatives after complement attack on macrophages: role of channel formation. J. Immunol. 136:4637-4643.

10. Needleman, P., S. Moncada, S. Bunting, J.R. Vane, M. Hamberg, and B. Samuelsson. 1976. Identification of an enzyme in platelet microsomes which generates thromboxane A 2 from prostaglandin endoperoxides. Nature (Lond.). 261:558-560.

11. Smith, W.L., and L.J. Marnett. 1991. Prostaglandin endoperoxide synthase: structure and catalysis. Biochim. Biophys. Acta. 108:1-17.

12. DeWitt, D.L. 1991. Prostaglandin eudoperoxide synthase: regulation of enzyme expression. Biochim. Biophys. Acta. 1083:121-134.

13. Wrenshall, L.E., F.B. Cerra, A. Carlson, F.H. Bach, and J.L. Platt. 1991. Regulation of $\mathrm{T}$ lymphocyte responses by heparan sulfate. J. Immunol. 147: 455-459.

14. Wrenshall, L.E., F.B. Cerra, R.K. Singh, and J.L. Platt. 1995. Heparan sulfate initiates signals in murine macrophages leading to divergent biological outcomes. J. Immunol. 154:871-880.

15. Spurney, R.F., and T.M. Coffman. 1995. The role of eicosanoids in transplant rejection. In Inflammation Mediators and Pathways. R.R. Ruffolo and M.A. Hollinger, editors. CRC Press, Inc., Boca Raton, FL. 173-181.

16. Platt, J.L., G.M. Vercellotti, B.J. Lindman, T.R. Oegema, Jr., F.H. Bach, and A.P. Dalmasso. 1990. Release of heparan sulfate from endothelial cells: implications for pathogenesis of hyperacute rejection. J. Exp. Med. 171: 1363-1368.

17. Parker, W., D. Bruno, Z.E. Holzknecht, and J.L. Platt. 1994. Xenoreactive natural antibodies: isolation and initial characterization. J. Immunol. 153: 3791-3803.

18. Saadi, S., and J.L. Platt. 1995. Transient perturbation of endothelial integrity induced by antibodies and complement. J. Exp. Med. 181:21-31.

19. Platt, J.L., B.J. Lindman, R.L. Geller, H.J. Noreen, J.L. Swanson, A.P. Dalmasso, and F.H. Bach. 1991. The role of natural antibodies in the activation of xenogenic endothelial cells. Transplantation (Baltimore). 52:1037-1043.

20. Masferrer, J.L., B.S. Zweifel, P.T. Manning, S.D. Hauser, K.M. Leahy, W.G. Smith, P.C. Isakson, and K. Siebert. 1994. Selective inhibition of inducible cyclooxygenase-2 in vivo is antiinflammatory and nonulcerogenic. Proc. Natl. Acad. Sci. USA. 91:3228-3232.

21. Chomczynski, P., and N. Sacchi. 1987. Single-step method of RNA isolation by acid guanidinium thiocyanate-phenol-chloroform extraction. Anal. Biochem. 162:156-159.

22. Vane, J.R., E.E. Anggand, and R.M. Botting. 1990. Regulatory func- 
tions of the vascular endothelium. N. Engl. J. Med. 323:27-36.

23. Smith, W.L. 1986. Prostaglandin biosynthesis and its compartmentation in vascular smooth muscle and endothelial cells. Annu. Rev. Physiol. 48:251262 .

24. Habib, A., M.E. Martinuzzo, L.O. Carreras, S. Levy-Toledano, and J. Maclouf. 1995. Increased expression of inducible cyclooxygenase-2 in human endothelial cells by antiphospholipid antibodies. Thromb. Haemostasis. 74:770777.

25. Ramadan, F.M., G.R. Upchurch, B.A. Keagy, and F. Johnson. 1990. Endothelial cell thromboxane production and its inhibition by a calcium channel blocker. Ann. Thorac. Surg. 49:916-919.

26. Carreras, L.O., and J. Maclouf. 1993. The lupus anticoagulant and eicosanoids. Prostaglandins Leukot. Essent. Fatty Acids. 49:483-488.

27. Karim, S., A. Habib, S. Levy-Toledano, and J. Maclouf. 1996. Cyclooxygenase-1 and -2 of endothelial cells utilize exogenous or endogenous arachidonic acid for transcellular production of thromboxane. J. Biol. Chem. 271: 12042-12048.

28. Ristimaki, A., and L. Viimikka. 1992. Modulation of prostacyclin pro- duction by cytokines in vascular endothelial cells. Prostaglandins Leukot. Essent. Fatty Acids. 47:93-99.

29. Ristimaki, A., S. Garfinkel, J. Wessendorf, T. Maciag, and T. Hla. 1994. Induction of cyclooxygenase- 2 by interleukin- $1 \alpha$. Evidence for post-transcriptional regulation. J. Biol. Chem. 269:11769-11775.

30. Crowl, R.M., T.J. Stoller, R.R. Conroy, and C.R. Stoner. 1991. Induction of phospholipase A2 gene expression in human hepatoma cells by mediators of the acute phase response. J. Biol. Chem. 266:2647-2651.

31. Oka, S., and H. Anita. 1991. Inflammatory factors stimulate expression of group II phospholipase A2 in rat cultured astrocytes. Two distinct pathways of the gene expression. J. Biol. Chem. 266:9956-9960.

32. Lin, L.L., A.Y. Lin, and D.L. DeWitt. 1992. Interleukin-1 $\alpha$ induces the accumulation of cytosolic phospholipase $A_{2}$ and release of prostaglandin $E_{2}$ in human fibroblasts. J. Biol. Chem. 267:23451-23454.

33. Forman, B.M., P. Tontonoz, J. Chen, R.P. Brun, B.M. Spiegelman, and R.H. Evans. 1995. 15-Deoxy- $\Delta^{12,14}$-prostaglandin J2 is a ligand for the adipocyte determination factor PPAR $\gamma$. Cell. 83:803-812. 